\title{
Royal Soap?
}

\section{Class and Gender in the Queen Caroline Affair}

\author{
Nicholas Rogers
}

Within the last decade the notion of class, whether as class struggle or class consciousness, has increasingly come under critical scrutiny. Feminists like Joan Scott have enjoined historians to abandon the master narratives of class in favour of a mode of analysis that gives critical weight to the linguistic construction of gendered identities. ${ }^{1}$ At the same time, historians have begun to rethink the languages of class in other ways, repudiating interpretations that unreflexively 'read off' class from concepts like 'experience' and its sociological manifestations. ${ }^{2}$ In the latest version of this 'linquistic turn,' Patrick Joyce has mapped out the plurality of identities of the industrial workers of nineteenth-century Britain, arguing that populism was a more compelling and resonant discourse of social difference than that of class. "There is life after class," he declares, pointing out that the more latitude we give that term, the more useless it becomes. ${ }^{3}$

At stake in this revisionist social history is the question of whether language constitutes social reality rather than being constituted by it. Or to rephrase the problem less starkly, whether language is fundamentally a self-referential discourse whose very materiality and ubiquity shapes experience, or whether it is a field of ideological contention whose multi-vocality registers a struggle for different meanings, and by extension the social practices that fuel them. For all his interest in the diverse forms of popular idiom and their plausible class notations, Joyce continually reasserts the autonomy of discursive constructions of reality, so that no fully-fledged form of class consciousness can emerge until populist discourses have been displaced, albeit in the early twentieth century. Consequently populism continuously subsumes class in the classic era of industrial capitalism. How class struggle might inflect and transform the language of radical populism is systematically sidelined.

I want to address these issues by looking at one of the first populist moments of the nineteenth century, the Queen Caroline affair. This was the cause célèbre of 1820 , a political bombshell that exploded throughout Britain. From Caroline's sudden return to Britain to reclaim her regal rights until her infamous trial for adultery a few months later, the public was fixated both by the personal battle between the royal dandy, George IV, and his dubiously respectable consort, and by its political and constitutional ramifications. From the beginning the public rallied to the cause of the

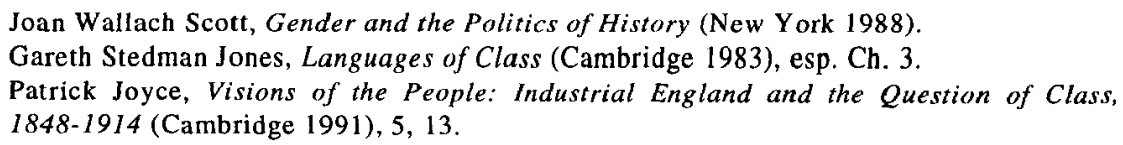


and during the French Wars many upper-class women did their patriotic duty raising funds, sewing clothes and presenting colours to volunteer regiments. ${ }^{12}$ In the aftermath of the war women participated visibly in the victory processions; they protested vigorously against the imprisonment of their husbands during the northern strikes of 1818; and they organized themselves into female union societies, imparting a new presence to the great meeting for Parliamentary reform at St. Peter's Field, Manchester. $^{13}$

None the less 1820 saw a conspicuous spurt in female activism. Middle-class wives and daughters attended civic and parochial deputations to the Queen. They organized tea parties in her honour and their presence was very conspicuous at the Queen's triumphal procession to St. Paul's in November where they were said to have crowded the balconies hours before the formal proceedings began. ${ }^{14}$ Lower-class women played their part too. At Sibsey, on the abandonment of the bill, "men, women and children of both sexes assembled rejoicingly, then paraded the streets ... accompanied by a band of music." ${ }^{15}$ At Liverpool, the female cordwainers and several female friendly societies, one specifically named after the Queen, joined the jubilant procession in her honour, as indeed they did at Chorley. ${ }^{16}$ So close was the bond that some working-class women felt towards the Queen that they presented her with gifts. The female straw-plait weavers of the midlands offered her a bonnet; the Loughborough lacemakers a dress; five poor women from Sandwich even sent her "a very fine fat pig." 17

A particularly novel way of garnering support for the Queen was for women to address her in their own right. Papers of very different political persuasions such as the Times and the Republican encouraged women to associate in this manner, on the grounds that it was "natural that a more exquisite feeling should exist in their bosoms on this subject, than in those of their husbands, fathers, or brothers." ${ }^{18}$ To this call women responded. Although a few middle-class women had qualms about entering

12 Linda Colley, Britons: Forging the Nation, 1707-1837 (New Haven \& London 1992), 250-263. On the female debating societies see Donna Andrew (comp.), London Debating Societies, 1775-1799 (London forthcoming).

13 Colley, Britons, 237; Thompson, The Making, 454-6; Robert Walmsley, Peterloo: The Case Reopened (Manchester 1969), 151-3. On the female protests against the imprisonment of their husbands during the 1818 strikes, see To all Persons Friendly to, and Desirous of Establishing An Union on Legal Principles (Manchester 1918), to be found in Public Records Office (PRO), 42/181. I thank Fred Donnelly for this reference.

14 Leeds Mercury, 2 December 1820. "As early as eight o'clock crowds of elegantly dressed ladies took their seats in the different houses along the line of procession. Their appearance contradicted ... the vile slanders of those who have unblushingly asserted that none but the very meanest order of Females commiserated with the sufferings of the Queen. We never, on any occasion, recollect to have seen a brighter or more fascinating assemblage of female loveliness ... than the windows of Fleet-street and Ludgate-hill presented."

15 Times, 17 November 1780.

16 Liverpool Mercury, 24 November, 1 December 1820.

17 Morning Chronicle, 20 November 1820; Laqueur, "The Queen Caroline Affair," 427.

18 Republican, 21 April, 21 July 1820; Times, 28 September 1820. 
the public sphere in this way - the organizer of one address apologetically remarked that she gave up a week "usually devoted to the more tranquil and not less honourable cares of her family" to rally support for the Queen ${ }^{19}$ - many women took to the task with gusto and thousands of signatures were raised in a matter of days. More than twenty female addresses were presented to Caroline soliciting over 70,000 signatures. They not only hailed from established radical centres such as London, Bristol, Nottingham and from the radical North, but also from St. Ives near Huntingdon, Truro and Beverley. ${ }^{20}$ Even in towns where women were denied the opportunity to sign separate addresses, they could be active on the Queen's behalf. At Newcastle, one woman brought five of her sons to sign the address, threatening to ostracize them if they refused. Another attempted to sign the scroll and "when she was told she could not put down her name, observed, she was sorry for it, for it was a woman's cause." 21

In these addresses women frequently identified with the queen as the bereaved mother and victimized wife, in terms that often expressed their own anxieties or experience of domestic strife. Caroline's daughter, Princess Charlotte, had been a popular figure, idealized as a romantic heroine who had defied her father and married for love before dying in childbirth in 1817. Her loss had been especially felt by her mother, or so it was projected, because Caroline's access to her daughter had been restricted upon separation from her husband and she was neither informed about nor invited to Charlotte's funeral. Caroline's own ill-treatment by the future George IV was, of course, notorious. The Prince, whose earlier marriage to the Catholic divorcee, Mrs. Fitzherbert, had never been officially recognized, had been induced to marry his cousin, Caroline of Brunswick, in the hope that Parliament would redeem his debts. It was a marriage of convenience from the beginning, and within a year the royal couple had gone their separate ways. Not content with this estrangement, however, George vigorously probed into Caroline's extra-marital behaviour in the hopes of securing a divorce while he caroused with his mistresses. (Figure 1) When female addressers alluded to the 'Delicate Investigation' of $1807,,^{22}$ the occasion when the Prince unsuccessfully accused his wife of bearing an illegitimate child, they placed the 1820 ordeal within the same persecutory narrative. Indeed, because that ordeal was carried on before an unreformed Parliament rather than a normal court of law, and according to procedures that seemed highly prejudicial to the defence, it was doubly damning. Not only did it shield the King's infidelities from public exposure

19 Champion, 19 August 1820. The address stressed how "unaccustomed" the ladies were to "public acts."

20 Nine female addresses are listed in the Annual Register (September 1820), 423-4. From this source and from newspapers I have recovered the following: Ashton-under-Lyne, Bath, Beverley, Bristol, Bray, Edinburgh, Exeter, Halifax, Leeds, Leicester, London (Married Ladies), Manchester, Marylebone (Married Ladies), Nottingham, St. Anne Limehouse, St. Ives, St. Luke's Islington, Sheffield, Southampton, Truro, Warrington, Worcester.

21 Champion, 16 July 1820.

22 See the address from the Female Inhabitants of Halifax, printed in the Champion, 16 September 1820 . 
10 left history

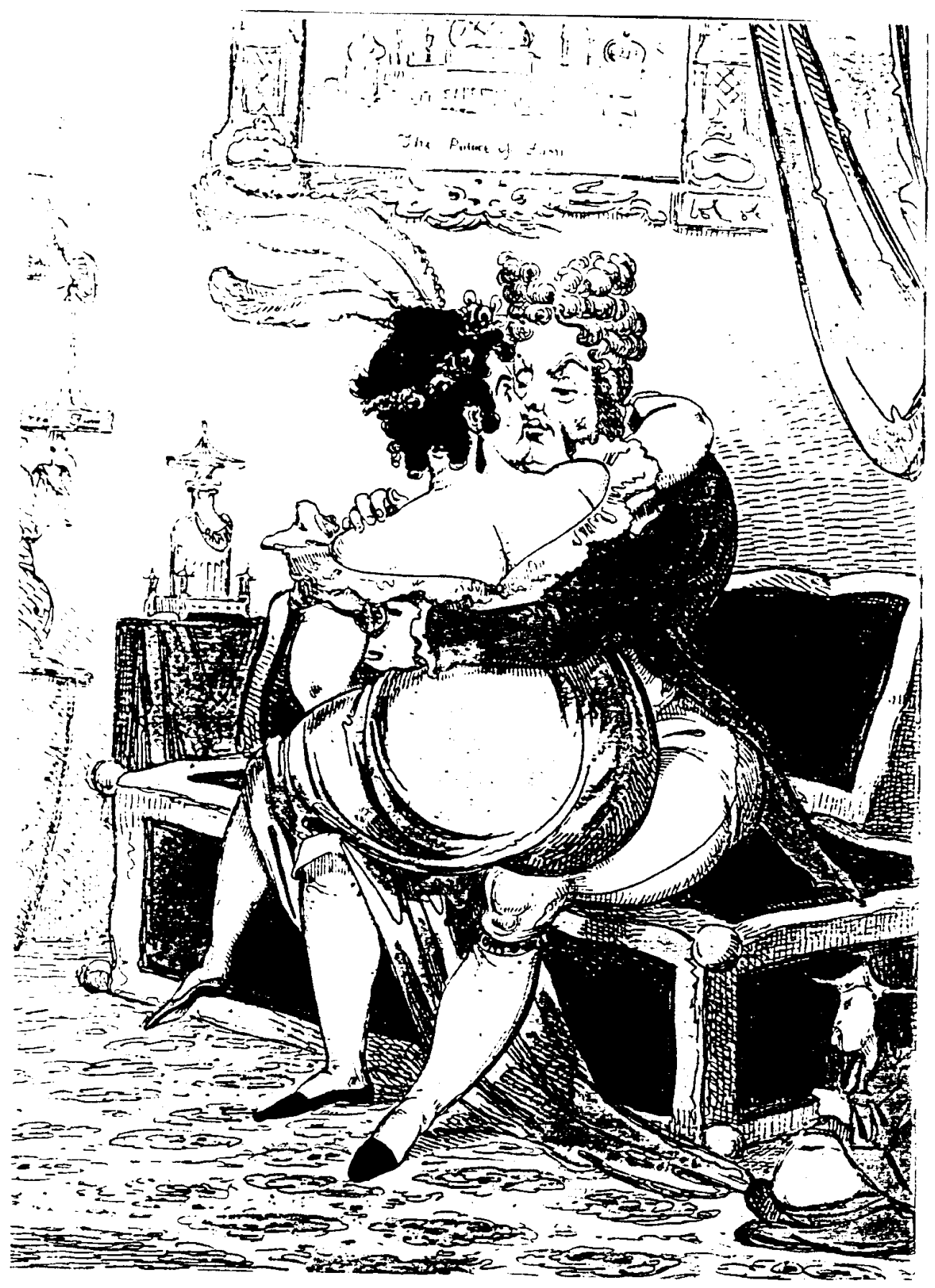

Figure 1: George IV at Brighton, with mistress and brandy bottle . 
and reinforce the double standard, but it set dubious precedents for the future. As the Ladies of Edinburgh insisted in their address to the Queen:

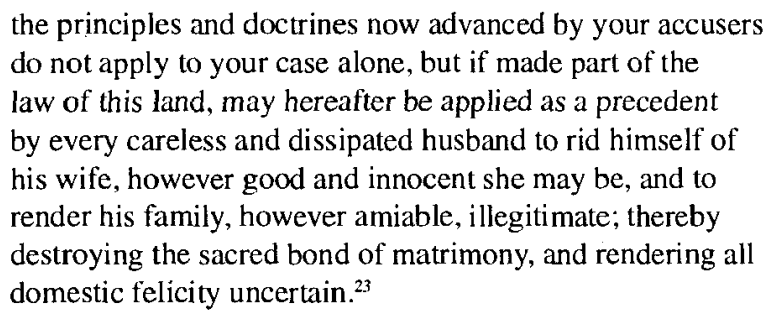

Caroline's marital ordeal was thus identifed with women's vulnerability within marriage; her legal disabilities with theirs. In defending her honour female addressers were implicitly vindicating their own status as wives and mothers within the companionate family. Yet this rather sentimental and largely middle-class reconstruction of Caroline had to address the thorny question of Caroline's innocence and purity. Caroline, after all, was no paragon of virtue. There were enough rumours circulating about her indiscretions at the time of the 'Delicate Investigation' to question her respectability, let alone the gossip that crossed the channel concerning her gaddings on the continent. Lady Bury saw her at a Genevan party in 1814 "dressed en Venus, or rather not dressed further than the waist." Others reported her posing for a portrait as the repentant Magdalene, "her person very much exposed." ${ }^{24}$ More significantly, her association with her Italian courier, Bartolomeo Bergami, appeared to be more than a close working relationship, as loyalist caricatures of the couple mischievously depicted. ${ }^{25}$ (Figure 2) Caroline's supporters sometimes tried to fob all this off as a matter of manners rather than morals. Her flamboyance and lack of protocol had been misinterpreted. "A woman of unguarded, and sometimes of even unfeminine manners," remarked the Examiner, her only fault was a "grossness of impulse." ${ }^{26}$ Yet as a symbol of innocence there is no doubt that Caroline was an unstable signifier.

To some this did not matter. Since Caroline had been denied consortium by her husband, she was perfectly justified in taking a lover; a line of argument that had a particular resonance for plebeian women, for whom common-law marriages (and desertion) were not that unusual. ${ }^{27}$ In any case, the spectacle of a pot-bellied

23 British Press, 14 September 1820.

24 John Stevenson, "The Queen Caroline Affair," 119; Alan Palmer, George IV (London 1975), 85.

25 See The New Pilgrim's Progress; or, A Journey to Jerusalem (London 1820) in Edgell Rickword (ed.), Radical Squibs and Loyal Ripostes (Bath 1971), 237-68.

26 Examiner, 27 August 1820.

27 Anna Clark, "Queen Caroline," 48; John R. Gillis, For Better, For Worse. British Mar riages, 1600 to the Present (New York 1985), 111, 190-228; David A. Kent, "Gone for a Soldier': Family Breakdown and the Demography of Desertion in a London Parish, 1750 1791," Local Population Studies, 45 (1990), 27-42. Kent reveals that over 12\% of all parish examinations for St. Martin-in-the-fields, 1750-1791, involved desertions. 


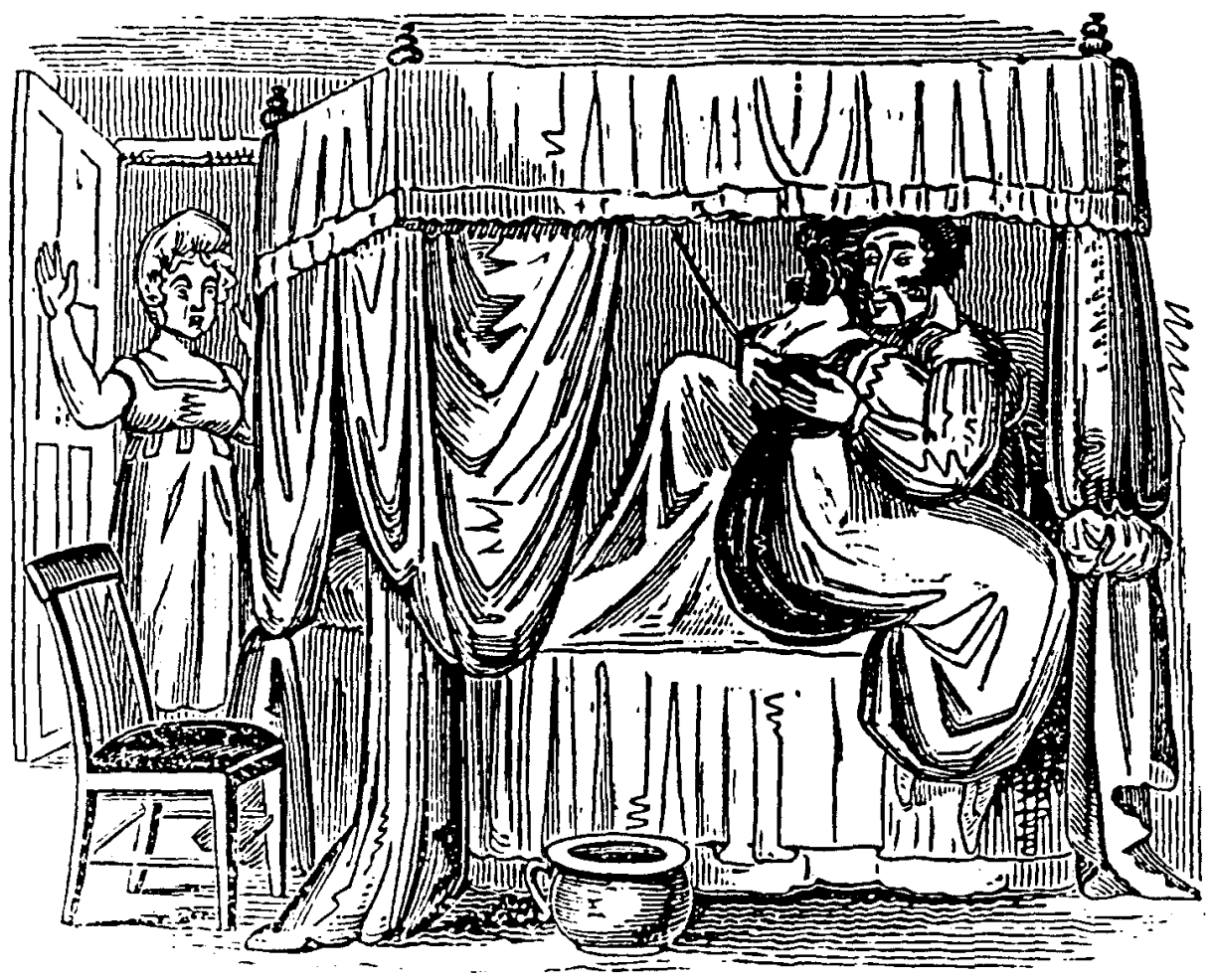

Figure 2: Harmless Amusement.

debauchee taking his wife to court for adultery smacked of sheer hypocrisy, as did the spectacle of known aristocratic libertines sitting in judgment upon her. Indeed, in the ribald tradition of plebeian radicalism, the whole affair took on a comic and satirical character. ${ }^{28}$ The King had been cuckolded; his masculinity undermined by a defiant female who had paid him in kind for his infidelities. When the people of Kentish Town carried about a "hideous, bloated effigy" of the King at the abandonment of the Bill of Pains and Penalties, they were no doubt thinking that he had received his comeuppance in more ways than one. ${ }^{29}$ 
For those who wished to sustain the image of Caroline as the innocent, injured party, there was always the escape route of the trial itself. The King did not prosecute the Queen for divorce, at least not directly. That would have brought his own infidelities on the carpet. Instead, the law officers of the crown introduced a Bill of Pains and Penalties in the Lords in an attempt to degrade the Queen for an 'adulterous intercourse' with Bergami, adding a divorce clause as a corollary. Normally such bills were reserved for near-treasonable offences of public import, not matrimonial causes, but the King was interested in a swift divorce before a court he could trust to do his business. Lord Liverpool protested that had the Queen respected her bargain to stay out of the country on a generous pension, all this would have been unnecessary. ${ }^{30}$ To this the Queen's supporters replied that the whole process was unconstitutional and 'unmanly', especially so, since the King was not officially a party to the suit. Wooler declared such bills were "mere arbitrary inventions, ... unwarrantable expedients to gratify the vengeance of power for destroying persons whose actions had not exposed them to punishment by law." ${ }^{11}$ The evidence culled to substantiate this "mockery of justice" was equally damaging. Collected by the Hanoverian envoy to Rome through the auspices of spies and informers and presented to the Lords in a green bag, it reeked of intrigue and conspiracy. The bag quickly became a symbol of all that was rotten in the case, and the Queen's supporters were soon trampling green bags under foot, parading them derisively on a pole, or using them as a football. ${ }^{32}$ To compound matters, the actual testimony used in the trial was far from conclusive. The Crown prosecutors mustered evidence of Bergami kissing and possibly fondling the Queen, of preparing her bath and (as secretaries were wont) having easy access to her bedroom. They speculated on what went on during the sea voyage from Jaffa to Italy, when Caroline and Bergami reclined on the deck of a polacca beneath a closed awning. But ultimately the Attorney General resorted to the argument that the Queen's 'degrading familiarity' with Bergami was prima facie evidence of her adultery. When the prime Italian witness, Theodore Majocchi, wilted under cross-examination, the opposition press had a field day. His frequent response to Brougham's questioning, "Non mi ricordo," became the butt of ridicule and satire, displayed on placards and converted into verse:

Sometimes it means "I do forget,"

Sometimes it means "I don't,"

And very often it will stand

For "rather not" or "won't."

Sometimes with very little help

30 On the failure to negotiate a settlement with the Queen to keep her in exile and the decision to introduce a bill of Pains and Penalties against her, see J.E. Cookson, Lord Liverpool's Administration: The Crucial Years 1815-1822 (Hamden, Conn. 1973), 229-249.

31 Black Dwarf, 30 August 1820.

32 Liverpool Mercury, 25 August 1820; British Press, 14, 30 November 1820; Morning Chronicle, 26 November 1820. 


\section{4 left history}

It means both No and Yes,

Or something rather less than more,

Or rather more than less. ${ }^{33}$

In the circumstances the Queen's innocence seemed clear enough. Would she have returned to England, her supporters asked, if the evidence against her had been incriminating? Under British law and in the face of questionable testimony, was she not entitled to the presumption of innocence?

Popular sympathy for the Queen could draw on male chivalry and female disgust at her ill-treatment by her husband. But it also drew on clear comparisons between the Queen's predicament and those of the politically excluded. Just as the Queen was the victim of ministerial power, and by extension, of the 'Borough-mongering System,' so, too, was the bulk of the population whose post-war economic grievances had been ignored and whose meetings had been repressed. At the time of the Caroline affair, a good many radical and labour leaders were in jail or awaiting trial, ${ }^{34}$ often, as was the Queen, on the testimony of spies and informers. This was recognized by the radical press and by the Queen's supporters, who saw in the Queen's ordeal an echo of their own oppression. Many addresses linked the Queen's cause with the constitutional rights of the people. Some alluded to other victims of ministerial power such as Henry Hunt, the radical orator arrested for his role at Peterloo. ${ }^{35}$ Those from Manchester predictably identified the Queen's plight with the assault upon popular liberties at St. Peter's Field the previous year, when eleven people were killed and over 400 injured by the sabres of the local Yeomanry Cavalry. "The same power which scourged us is now oppressing you:" the artisans and mechanics declared, "it is not less our interest than our duty, therefore, to stand up against your Majesty's enemies, who are also the enemies of the rights and liberties of the whole People." 36 These sentiments were voiced in both Manchester and Ashton-under-Lyne on the anniversary of Peterloo where the Queen's cause was taken up by the mourners. ${ }^{37}$ They were reiterated at the celebrations of Henry Hunt's birthday in industrial Lancashire, where toasts to the Queen accompanied those to Hunt, to Cartwright, to the "cause of liberty all over the world" and significantly, to "Labour, the source of wealth." ${ }^{38}$ And somewhat later,

33 Examiner, 27 August 1820.

34 Thompson cites 17, including Henry Hunt, Thomas Wooler, Richard Carlile, Sir Francis Burdett and Sir Charles Wolseley. Thompson, The Making, 768. To this list one should add the spinners and weavers imprisoned under the Combination Acts. See A. Aspinall, The Early English Trade Unions (London 1949), 314-5; R.G. Kirby \& A. E. Musson, The Voice of the People: John Doherty, 1798-1854 (Manchester 1975), 22-23.

35 See the address from the women of Ashton-Under-Lyne, printed in the Manchester $O b$ server, 25 November 1820 .

36 Black Dwarf, 30 August 1820 . For similar sentiments, see the address of the females of Ashton-under-Lyne, printed in the Manchester Observer, 25 November 1820.

37 Manchester Observer, 19 August 1820. A copy can be found in PRO, HO 40/14/167-170.

38 Manchester Observer, 11, 18, 25 November 1820. The Queen was toasted at radical meetings at Manchester, Oldham, Preston, Ashton-under-Lyne, Royton, Leigh, Bolton and 
on the release of the leaders of the striking cotton spinners from Lancaster Castle. ${ }^{39}$ They were also taken up at Liverpool, where a radical declared before a meeting of over 1,000 people that, "of all the Conspiracies entered into by the Ministers, this against the Queen was the most base - Even more base than that of Oliver and the Derby conspiracy; or than that by which Brandreth suffered, whose blood, with that of others shed upon the scaffold, still cried out for Vengeance." 40

The remark of the Liverpool radical revealed the insurrectionary impulse that still smouldered in the North and Midlands in the aftermath of the Cato Street conspiracy. But the central problem confronting the popular movement in 1820 was how to re-establish the radical platform in the wake of the Six Acts. Those acts, as is well known, placed very severe restrictions on popular assembly and the press, reinforcing the government's powers of search, arrest and imprisonment and closing down public space for the airing of popular grievances, whether political or economic. The Queen's affair provided the radicals with an opportunity to challenge this repressive regime and they took it. As early as January 1820 a London spy reported that "as Various Congregations were leaving their respective places of Worship fellows with Horns were proclaiming the arrival of the Queen and selling papers to that effect." 41 This proved premature, but once the agitation in favour of the Queen gathered momentum in June it proved virtually unstoppable. In the following month the same spy, John Shergoe, reported that "Men \& Boys have been employed by Benbow, Fairburn \&c to circulate in the metropolis \& for 50 miles round it, vast quantities of Bills, Placards and publications of a seditious and inflammatory nature, with a view to inflame the passions of the Lower orders into acts of Violence agst the Constituted Authorities \& ... to stop the investigation in the House of Lords respecting the Queen." ${ }^{42}$ Accompanying this sea of seditious and often ribald literature, were the mass meetings and processions to Brandenburg House, many of which were technically unauthorized. "Every Wednesday," wrote Creevy, referring to the parades through London to Hammersmith, " the scene which caused such alarm at Manchester is repeated under the very nose of Parliament and all the constituted authorities, and in a tenfold degree more alarming." 43 This may have been hyperbole, but the main point was correct. "All the six new acts that were to crush the radicals," remarked Wooler, "are only available for waste paper." ${ }^{44}$ The best that the government could do was to ensure the allegiance of the troops in the 150-odd barracks

Stockport. For this radical culture, see James Epstein, "Radical Dining, Toasting, and Symbolic Expression in Early Nineteenth-Century Lancashire: Rituals of Solidarity," Albion, 20, 2 (Summer 1988), 271-291.

39 Manchester Observer, 3 March 1821. The toast ran: "Queen Caroline - may she always remember that she has identified her interests with those of the people."

40 PRO, HO 40/15/135.

41 PRO, HO 40/15/6.

42 PRO, $\mathrm{HO} 40 / 15 / 33$.

43 Cited by Cookson, Lord Liverpool's Administration, 270.

44 Black Dwarf, 25 October. 1820. 
throughout the country - a goal that seemed disconcertingly difficult amid incidents of soldiers fraternizing with radicals and a near-mutiny in London. ${ }^{45}$

The central fact is that Caroline's supporters successfully reappropriated public space and created the conditions in which the ministry ultimately backed away from prosecuting the Queen. As Cobbett remarked, the abandonment of the bill was "THE PEOPLE'S TRIUMPH over those who had so long triumphed over them." ${ }^{46}$ This was recognized in the victory celebrations. Alongside the placards and transparencies heralding the triumph of 'Virtue' and 'Innocence' were those that underscored the popular contribution to the victory. On the first night of the rejoicings in London William Hone displayed a blue flag inscribed to "The People" over his house on Ludgate Hill. In Holborn, a fellow printer exhibited a transparency of the Queen whose motto ran: "The glorious effects of public opinion, and its best ally, a free press." On the Strand, another enclosed a printing press within a triumphal arch over which hung a Cap of Liberty, the emblem of popular defiance against repression and of popular rights, both legal and democratic. ${ }^{47}$ In Southwark, where Cobbett believed the illuminations to have been brightest, a supporter displayed a bust of the Queen encircled in laurel leaves. Underneath were the very words that Caroline had used in her response to the artisans' address in August: "The industrious classes constitute the chief energy of the nation. In the great fabric of society, they are the strength at the bottom which supports the ornament at the top." ${ }^{48}$ Outside of London, too, the people's contribution to the victory was emphasized: at Chorley with a banner applauding "The Power of Public Opinion"; at Dewsbury, with the motto "Public Opinion triumphant"; at Linlithgow, with a representation of "Britannia in triumph, holding a Cap of Liberty, and a British Tar holding a flag with the inscription 'Britons never shall be slaves." 49

This aspect of the 1820 demonstrations has been played down in accounts of the Queen Caroline affair, which have concentrated instead on the more traditional, transgressive character of collective action; at least outside of London. Craig Calhoun, for instance, saw the jubilations surrounding the bill as spontaneous rather than

45 PRO, HO 40/14/152-3, 208; 40/15/139-40; Stevenson, "The Queen Caroline Affair," 123-4. Several privates in the Leicestershire militia actually had the courage to address the Queen. The Lord Lieutenant of the county, the Duke of Rutland, demanded to know who they were, but received no satisfaction from Aldermen Wood, who informed him instead that he had received an address from 300 more men sympathizing with their action. See Black Dwarf, 30 August 1820.

46 Cobbett's Weekly Political Register, 18 November 1820, 1211.

47 Examiner, 12 November 1820 . On the richly connotative character of the Cap of Liberty, see James Epstein, "Understanding the Cap of Liberty: Symbolic Practice and Social Conflict in Early Nineteenth-Century England," Past and Present, 122 (February 1989), 75-188.

48 Examiner, 12 November 1820; Cobbett's Weekly Register, 18 November 1820, 1214. For the Queen's reply to the artisans and mechanics' address, see the Champion, 19 August 1820,531 .

49 British Press, 25 November 1820; Leeds Mercury, 25 November 1820; Liverpool Mercury, 1 December 1820 . 
organized, as more prominent in the rural areas of the south than in the radical North, as more carnivalesque than radical. The agitation, he claimed, represented a "jarring shift away from that which led to Peterloo." "50" Similarly, Thomas Laqueur, while recognizing that the celebrations constituted a "massive, unprecendented political mobilization against an incumbent government," viewed them as "highly personalized," xenophobic, and "still expressed through the rituals of the old regime." 51 Indeed, both invoked, albeit in somewhat different contexts, Max Gluckman's notion of the 'rituals of rebellion' to suggest that the demonstrations, and the discourses in which they were embedded, were parodying power rather than subverting it. ${ }^{52}$

It is certainly true that the jubilations resonated with the rituals of inversion. William Hone's transparency (Figure 3), exhibited on three occasions in November 1820 , depicted a triumphant and incandescent Britannia displaying a Cap of Liberty

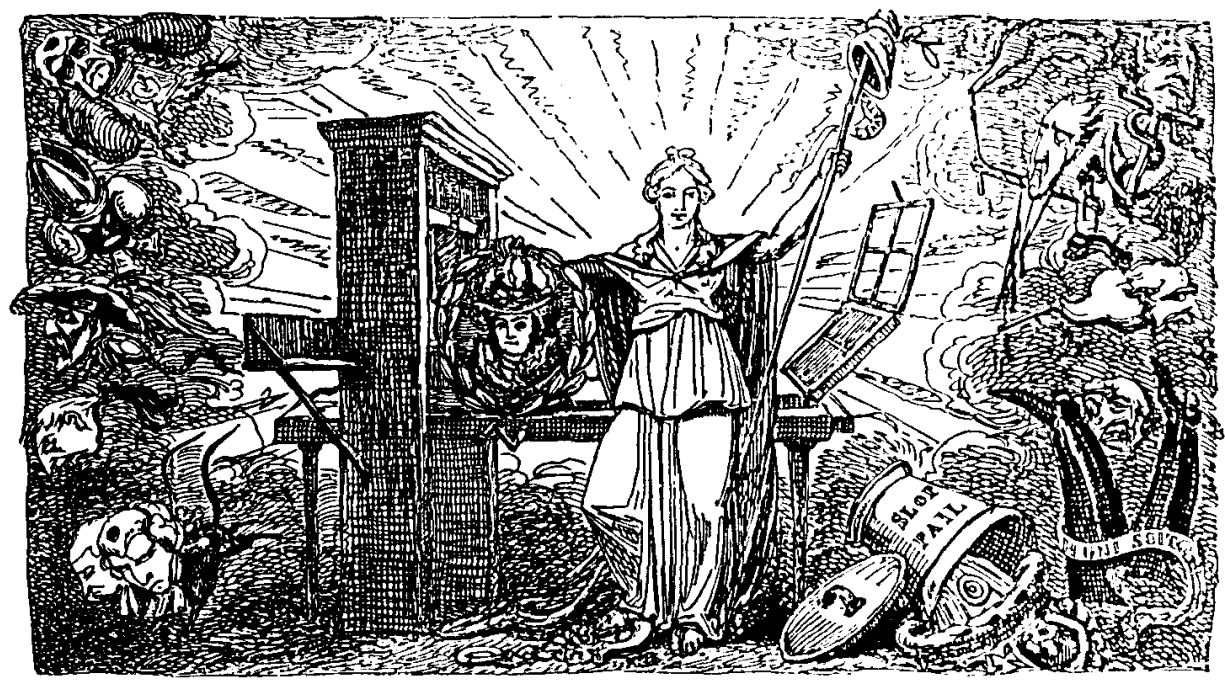

Figure 3: Willaim Hone's transparency, designed by Gruikshank, celebrating the abandonment of the Bill of Pains and Penalties, November 1820.

50 Calhoun, Class Struggle, 108-115.

51 Laqueur, "The Queen Caroline Affair," 456-7, 464-5.

52 Calhoun, Class Struggle, 114n; Laqueur "The Queen Caroline Affair," 465n. 
in one hand and a wreath of the injured Queen in the other, while ministerial vermin scattered in all directions. ${ }^{53}$ As for the King himself, he was submerged in the filth of his own accusations, his boots and crotch in the air, his crown bespoiled by a slop pail in which floated a tricoleur. It was an image that appropriated patriot virtue for the Queen, lampooned loyalist alarmism, specifically the accusation that Caroline's supporters were Jacobin subversives, and proudly proclaimed the power of the press. It also literally turned the King upside down.

Such symbolism was familiarly carnivalesque, as were many of the street jubilations. They featured bells, bands, fireworks, and illuminations. They involved attacks upon aristocratic supporters of the bill, and jeers against known adulterers, especially the King himself, who was reviled in the familiar idiom of cuckoldry or proclaimed, with deep irony, as one who had not been cuckolded by his 'innocent' Queen. ${ }^{54}$ They often culminated in effigy-burnings of the principal Italian witnesses; not out of sheer xenophobia, but as a demonstration of revulsion against the perjured lackeys of a corrupt ministry. Hence their autos-da-fé in conjunction with combustible green bags. ${ }^{55}$

The demonstrations also featured dinners for the better sort and tokens of largesse for the crowd: ale and ox-roastings. In the larger centres such victuals were often raised by subscriptions from the Queen's supporters and were dispensed to the poor. At Horbury, for instance, four fat sheep were purchased by public subscription and roasted at the public houses for 420 poor men, who were each given a pint of ale. (Their female counterparts had to make do with tea.) ${ }^{56}$ In smaller centres local gentry would do their paternal duty in a similar fashion, and in some of the new industrial districts factory masters assumed the same role. At Heckmondwike, for example, it was reported that "the principal manufacturers regaled their workmen in the most liberal manner with roast beef, ale \&c." The same was true at Congleton, Knutsford and Nottingham, while at Merthyr Tydfil the ironmaster, William Crawshay, inaugurated the proceedings with an impressive cannonade. ${ }^{57}$

Yet to describe these demonstrations as simply carnivalesque, steeped in the paternalistic rituals of the old regime, would be to understate their complexity and significance. To begin with, many celebrations were not spontaneous expressions of joy at the abandonment of the bill. Although bells were rung and candles put out on the news of its withdrawl, many communities organized a 'general illumination' day,

53 For an exposition of the vermin, see The Political Showman - At Home! in Radical Squibs, 276-92.

54 See the demonstrations at Manchester and Orskirk, reported in the Liverpool Mercury, 1 December 1820 , where celebrants mischievously paraded flags on the abandonment of the bill with the words, "Heaven be praised! the king is not a cuckold!"

55 To underscore this point it is noteworthy that the Queen's own Italian witnesses were welcomed with a street parade when they arrived at Dover. See Champion, 7 October 1820.

56 Leeds Mercury, 9 December 1820.

57 Leeds Mercury, 18 November 1820; Laqueur "Queen Caroline Affair," 456; Bristol Mercury, 20 November 1820 . 
even weeks later. These were choreographed events, with parades, processions, public meetings, dinners, and allegorical transparencies, that is, magic lantern-type representations of the victory. Like the dinner toasts and the style and content of the processions, they expressed different and sometimes competing narratives of the event. Some saw the 'defeat' of the bill as an opportunity, however implausible, for a royal reconciliation, presumably on the fiction that the King had been ill-advised. Thus a transparency at Colchester portrayed "Fame, with a wreath; a Dove with an olive branch; two Crowns, with 'G.R.' and 'C.R.'" 58 The ladies of Tenterden, to take a contrary example, focussed on the Queen's innocence, staging a procession in which an "elegant figure of a female dressed in white satin, and richly ornamented with white ribbons" was paraded through the town. Others cast the withdrawl of the bill as a Whig victory. At Newent in Gloucestershire, for example, a person impersonating the Queen's counsel, the Whig M.P. Henry Brougham, was chaired through the village and assigned "an appropriate speech" for the occasion. ${ }^{59}$

In Lancashire, however, the celebrations were replete with radical signifiers. At Middleton, the procession of the green bag was led by a man wearing a Cap of Liberty, a symbolic act that no doubt fed conservative fears that radicals were using the Queen's cause to subvert the monarchy. (Figure 4) The evening's convivialities concluded with healths to Henry Hunt and to Parliamentary reform. At Haggate, on the moors near the Yorkshire border, celebrants toasted "The Queen - and may she advocate the cause of the people as they have done her." ${ }^{60}$ In Oldham, the radical message was as blunt. A cottage in Jackson's pits displayed in one window the motto "Non mi ricordo." Opposite was a slogan redolent of Peterloo: "Give us Liberty." 61

The celebrations were also contentious in a context to which I have already alluded: the control of public space. Tory magistrates sometimes refused to agree to general illuminations; or, because there was some doubt as to whether the laws pertaining to public meetings applied to "merry-makings," They did their utmost to compromise their success. ${ }^{62}$ Troops were alerted; special constables were enlisted. Publicans were threatened with the loss of their licenses if they tolerated disorders; and handbills were issued forewarning demonstrators of the magistrates' determination to suppress breaches of the peace and to protect those who chose not to illuminate. These injunctions sometimes had an inhibiting effect on the celebrations, at least in respectable quarters, but they rarely closed them down. Indeed, magistrates sometimes found that their authority to authorize a general illumination was pre-empted by local committees. At Devizes, the mayor attempted to intimidate a local printer

58 British Press, 25 November 1820

59 Morning Chronicle, 23 November 1820.

60 Manchester Observer, 2 December 1820

61 Manchester Observer, 25 November 1820.

62 Magistrates at Liverpool, Leeds and Manchester, among others, declined to sanction meetings. See PRO, HO 40/15/135; Manchester Observer, 18, 25 November 1820. For a discussion on whether licenses were required for "merry-makings," see Manchester $O b$ server, 6 January 1820 . 


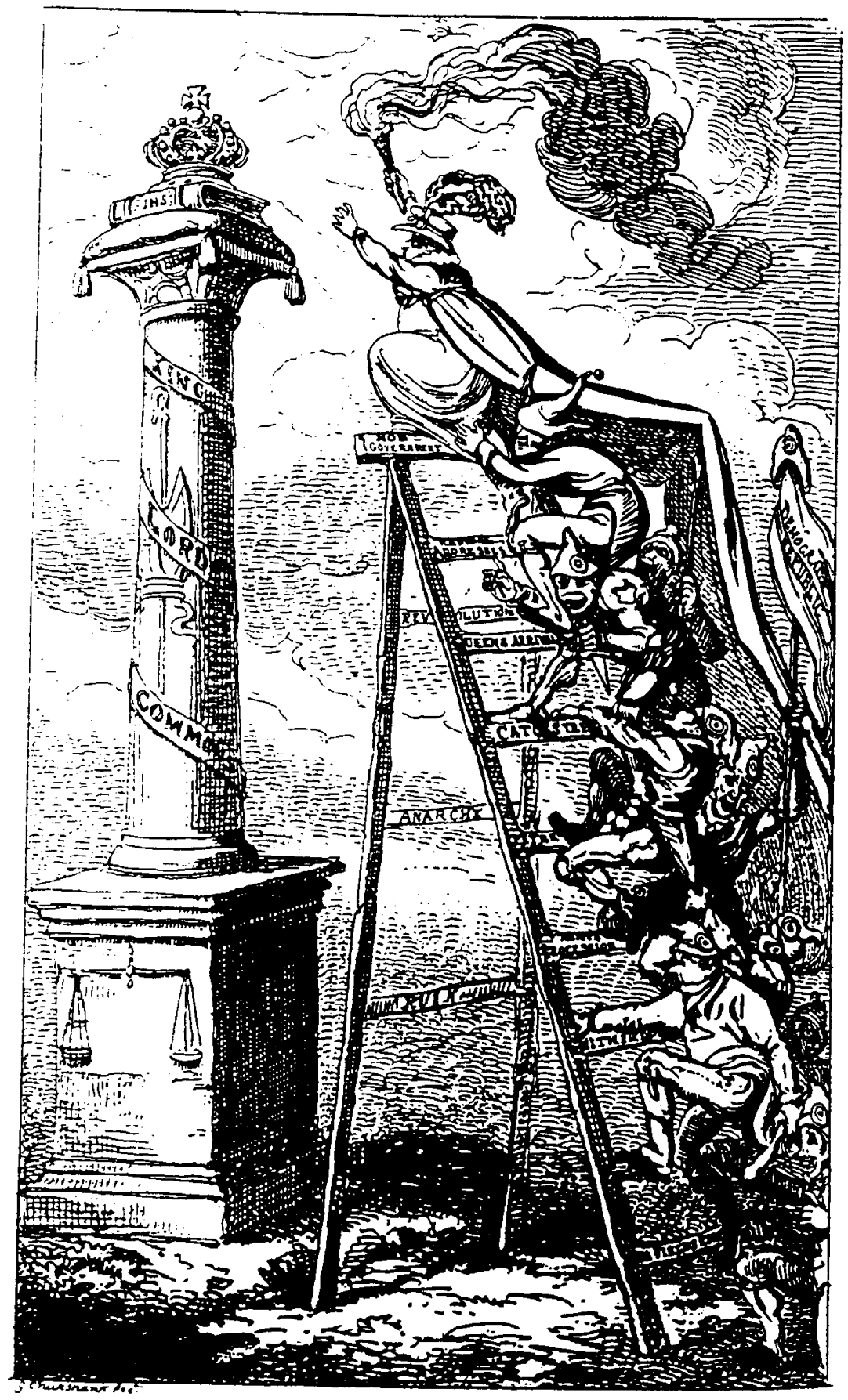

Figure 4: The Radical Ladder. 
into divulging who produced handbills for the illumination; without success. ${ }^{63} \mathrm{But}$ in the industrial districts of the North it is clear that the radicals initiated the celebrations. Many of them were artisans or shopkeepers. The leader of the Congleton Committee was a silk throwster. The Stockport Committee included two grocers, two druggists, two drapers, a baker, a shoemaker, clogmaker, patten-maker and a sweep. Those at Warrington were drawn entirely from "the working class of people." ${ }^{64}$ Their leadership grew out of the post-war struggles in the manufacturing districts, from the widespread strikes of 1818 and the attempt to establish a General Union of Trades, and from the rapid advance of radicalism beyond its late eighteenth-century, artisan strongholds. ${ }^{65}$

The demonstrations in the industrial North were also noteworthy for their relative soberness and discipline. There were few antics comparable to those at Stroud, where the inhabitants tied a green bag to an ox and pelted it with mud to signify what they felt about the Milan Commission (and perhaps, more covertly, a cuckolded King!) ${ }^{66}$ Nor did one see the scenes of disorder that broke out at Bath, where a high-spirited mob attacked the house of a local clergyman and several others "against whom they had taken umbrage" before the lancers were called in and the Riot Act read. ${ }^{67}$ Demonstrators in the larger cotton towns were organized into parades, with banners and streamers and renditions of radical Samuel Bamford's "God save the Queen." 68 They were enjoined not to give the magistrates and the specials any pretext for reading the Riot Act. "If there should be any great mob, or any appearance of riot," the handbill from Manchester ran, "the radicals too well know what to expect. They have not yet forgotten the 16th of August [Peterloo]." 69

This injunction was respected. The Bolton procession cheered as they passed the houses of well-known supporters of reform, and hissed at their enemies, but neither here nor elsewhere was there any attempt to enforce illuminations by a mob. Magistrates may have been elated that there were only partial illuminations, but they

63 PRO, HO 40/15/112-3.

64 PRO, HO 40/15/62 \& 194; Manchester Observer, 9 December 1820.

65 Thompson, The Making, 668-9; Aspinall, Early Trade Unions, chs. 7 \& 8; Kirby \& Musson, Voice of the People, 18-28.

66 Morning Chronicle, 22 November 1820.

67 Bath Herald, 18 November 1820, found in PRO, HO 40/15/143. The clergyman's house was attacked in an attempt to intimidate him into reinserting the Queen's name into the liturgy. At Grantham, a mob of agricultural labourers from Spittlegate and neighbouring villages used the celebrations to settle scores with the corporation. At East Barnet, "a gang of 20 fellows from Southgate" demanded money or ale from householders and " when refused at the manor house swore they would mark it for tomorrow and broke the bell at the gate upon parting." See British Press, 20 November 1820, and PRO, HO 40/15/106-7.

68 Printed in the Manchester Observer, 15 July 1820 . The rendition is anti-clerical, criticising members of the Anglican Church for refusing to include the Queen in the liturgy. The song also expresses the wish " $O$ may see purer rise/From the foul calumnies/Breathed by horrid spies/ God save the Queen."

69 Manchester Observer, 25 November 1820. 
had to concede, as did the Reverend James Norris, Manchester J.P., that "throughout the whole of these populous towns not a single pane of glass has been broken offensively, nor even attempted." 71

If the magistrates were relieved by the absence of disorder in the industrial districts of Lancashire, they would not have been happy with the demonstrators' re-appropriation of political space. This could take very pointed forms. In Oldham the auto-da-fé of Majocchi and Madame Demont, prime witnesses at the Queen's prosecution, took place on Brent Green, on the very spot where reform meetings had been held. At Ashton-under-Lyne the celebrants fixed a liberty tree on the pump in Old Street where radicals had formerly received a dousing at the hands of Church-and-King mobs. At Hadfield, further east, a village on the borders of Derbyshire, Majocchi's effigy was ritually executed and burnt at the same place where Tom Paine had been twenty years earlier. ${ }^{71}$ In this way the radicals recalled their early struggles for freedom and reaffirmed their determination to press on, as they did at Manchester. Here it was given out that "Jack Ketch" would publicly burn an effigy of "Old Hay" on the "plains of PETERLOO."72 Old Hay was the Reverend William Hay, stipendiary magistrate of the Salford sessions, ultra-Tory, execrated by the radicals for his role at Peterloo but rewarded for his services with the rectorship of Rochdale, one of the wealthiest livings in the country. ${ }^{73}$ The very thought of this champion of law and order being roasted in public sent the authorities scurrying to St. Peter's Field, only to discover that they had become dupes to a radical canard.

One final aspect of the Caroline agitation must be mentioned. That is the visible role of working men and women, not simply as anonymous members of the crowd, but as members of distinct associations. At Chester and Chorley, the victory processions of the Queen featured many friendly societies, some of which were certainly covert unions ${ }^{74}$ At Liverpool, over twenty trades, including the cordwainers, cabinet makers, nailmakers, hatters, gunmakers, ironfounders, coopers, carters, joiners and shipwrights, marched together with gentlemen and various friendly societies in an grand parade to show their solidarity for the Queen. ${ }^{75}$ In London a good number of trades showed common cause with the Queen by individually addressing her Majesty at Brandenburg House during her trial. They also collectively addressed the Queen, either in their capacity as the "artisans and mechanics" of London, whose address was signed by nearly 30,000 ; or under the banner of the "London industrial classes," or as part of the 4,000-strong procession of London's benefit societies representing no less than 250,000 members. ${ }^{76}$ These spectacular processions were not without their

70 PRO, HO 40/15/170-71. On Norris, see Joyce Marlow, The Peterloo Massacre (London 1971), 52-3.

71 Manchester Observer, 25 November, 9 December 1820. The paper cites Padfield, rather than Hadfield, but this appears to be a misprint.

72 Manchester Observer, 25 November 1820.

73 On Hay, see Marlowe, Peterloo Massacre, passim, and Walmesley, Peterloo, passim.

74 Manchester Observer, 30 December 1820; Liverpool Mercury, 1 December 1820.

75 Liverpool Mercury, 24 November 1820 
profanities. The pseudo-royalist parade of the brass founders and braziers, for example, featured three cumbrous knights in their armoured regalia and a fire extinguisher, whose ejaculations were greeted with "laughing applause." "At the same time these processions expressed craft pride and the dignity of labour, adding a new dimension to popular politics and new inflections of who constituted the 'People.'

The impressive discipline of the London trades was equally evident at the Queen's procession to St. Paul's in late November, when they acted as unofficial constables for the official cavalcade, "locked arm-in-arm," and then brought up the rear with a great variety of flags. ${ }^{78}$ But it was most evident at the funeral procession of the Queen twenty months later. Long before then the Queen's cause was in tatters, the victim of Parliamentary intransigence, Whig diffidence, and of her own willingness to accept a pension of $£ 50,000$ a year. Even so, the London trades were determined to have the last word. When it was learned that the government intended to take her body around rather than through London on its way to Harwich, London crowds blocked the procession route and forced the cortège to pass through the city despite the efforts of the Life Guards to prevent it. (Figure 5) Here the London trades, with their banners,

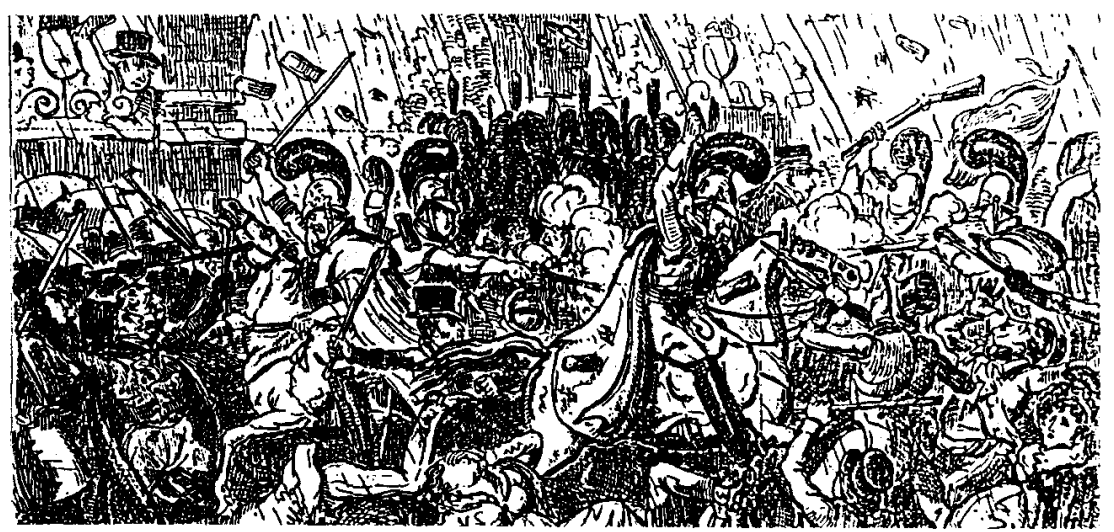

Figure 5: Crowds diverting the funeral procession of Queen Caroline, 14 August 1821.

77 See Robert Huish, Memoirs of Caroline, Queen Consort of England, 2 vols. (London 1821 ) 2: 614; cf. Laqueur, "The Queen Caroline Affair," 459-60, who makes much of this procession as expressing the "deep royalist sympathies" of Caroline's supporters. In fact the braziers' procession can be read as a parody or burlesque of royal pageantry. In this context one might ponder the many meanings that the extinguisher might signify in the context of 1820 . What fires were being put out? What liaisons were being celebrated or burlesqued? Was public space being consecrated or desecrated by this 'holy water'? What bodies were being cleansed by this 'royal douche'?

78 See the British Press, 30 November 1820; the Times, 29 November 1820; Manchester Observer, 9 December 1820; and A.M.W. Stirling, (ed.), The Letter-Bag of Lady Elizabeth Spenser-Stanhope..., 1806-1873, 2 vols. (London 1913), 1:353. "I know not whether I was most struck at the extra-ordinary nature of this triumphant procession, partaking of a strong rebellious feeling and made in the teeth of the Government," commented Lady Stanhope, "or at the tranquility with which it passed off." 


\section{4 left history}

emblems and flags bearing such insciptions as "Power of Public Opinion," "United We Stand," "Justice will triumph" and "Friends of Humanity," joined the procession..$^{79}$ It was a symbolic seizure of the Queen's cause, a defiant restatement of the people's right to political space, a thumbing of the nose at the political establishment. As a member of the crowd told Lord Stowell: "Ay, you gemmen thought you could carry everything your own way; but we'll show you the difference." 80

The Queen Caroline affair has sometimes been cast as a trivial event, a royal soap, a diversion from the main course of popular politics if not a regression to an earlier political idiom. Comic it often was, but the satires of Benbow, Cruickshank and Hone brought little credit to the monarchy, prompting in the wake of the Queen's acceptance of a pension a renewed call for a republican constitution. ${ }^{81}$ That call came from ultra-radical delegates at a meeting in Stockport in March 1821. Diversionary it was not, for the Queen's cause was always larger than the Queen. As Caroline herself remarked during her trial: "Nobody cares for $m e$ in this business. This business has been more cared for as a political business than as the cause of a poor forlorn woman." ${ }^{2}$ This statement was only partially true, for the Queen's cause as a "poor forlorn woman" was often inscribed within a domestic ideology that cherished connubial felicity as a staple of the social order. Equally it addressed the experiences of women for whom marital breakdown was commonplace and for whom new sexual freedom and assertiveness was a desideratum. The Queen was an unstable signifier of female purity let alone passivity, but this very instability enabled women of different sexual politics to identify with her predicament in unprecedented ways and to boost her support within her own sex.

Yet the Queen's cause also raised other issues of political and constitutional importance. The spectacle of the Queen undergoing a clearly political trial at the hands of an unreformed, venal Parliament on the basis of evidence largely gathered by spies and informers was a persistent theme in the Caroline agitation. Pace Laqueur, the affair was not overwhelmed by "a more compelling ... politically safe version of the story as domestic melodrama and royalist fantasy." ${ }^{83}$ It boosted the cause of Parliamentary reform, for which 33 petitions were heard in the Commons in the aftermath of the trial..$^{84}$ It cast the Queen's case as a parable of political iniquity as much as a parable of royal/marital persecution and hypocrisy, one that had a particular resonance within the radical community, especially in London and Lancashire. Moreover, the groundswell of support that the Queen's affair generated enabled the

79 Prothero, Artisans and Politics, 147-151; Huish, Memoirs of Caroline, 2:770-792.

80 G. Pellew, Life and Correspondence of First Viscount Sidmouth, 3 vols. (London 1847), 3: 356, cited in Stevenson, "Queen Caroline Affair," 137.

81 John Belchem, 'Orator' Hunt: Henry Hunt and English Working-Class Radicalism (Oxford 1985), 147-8.

82 Cited by Roger Fulford, The Trial of Queen Caroline (London 1967), 243

83 Laqueur, "The Queen Caroline Affair," 465.

84 Journals of the House of Commons, 76 (1821), 15-16 
radicals successfully to repossess the political space that had been denied them by the gagging acts of 1819 . The final months of 1820 not only saw the government back down before public opprobrium; it also saw the radicals begin to revivify a political culture that had suffered serious setbacks at Peterloo and Cato Street.

Caroline's supporters were always an uneasy and unstable alliance of Whigs, independents and radicals whose discourse was fundamentally populist, pitting the 'People' against irresponsible Privilege. This lent itself to inter-class alliances in support of the Queen. In Bristol, for example, Whig merchants and coalowners joined forces with local radicals on behalf of Caroline. So, too, did the leading Merthyr ironmaster, the unitarian William Crawshay, who a decade later would be locked in a bitter struggle with his workers in what was the first proletarian rising in Wales ${ }^{85}$ Elsewhere, too, the tokens of support for Caroline were clearly inter-class, even paternalist scenarios, with employers rallying to the Queen alongside their workers and subsidizing their celebrations. Yet in London and the industrial north, the demonstrations on behalf of the Queen were intimations of a working-class radicalism that was to blossom within little more than a decade. This was especially evident in the cotton towns, where the hurley-burley of crowd intervention, with its carnival of riot and sedition, had been replaced with the more disciplined language of burgeoning class solidarities.

To be sure, this radicalism was quintessentially 'producerist,' extolling the useful classes against the parasitical and conceding "fair profits to the manufacturer" in return for "reasonable wages to the workman." ${ }^{86}$ It was a radicalism that stressed democratic reform as the central solution to the resolution of social and economic grievances. Yet this should not detract from its class character. In the boom and bust economy of the textile industry, amid new forms of factory discipline, loss of independence, and the dislocation of the family economy, industrial exploitation and political oppression were intertwined. Protesting workers were subjected to a battery of legal and military sanctions in these years. Their unions were outlawed; their public meetings and strikes suppressed. Their ringleaders in the bitter strikes of 1818 were sentenced to two years in gaol. In these circumstances workers understandably looked to political solutions as an answer to their plight, and they seized the opportunity of the Caroline agitation to stimulate interest in reform and to restore the mass platform. It was a gamble that only partially paid off, generating divisions within the ranks about the efficacy of popular alliances with the Whigs. ${ }^{87}$ But it was not without its moment of triumph, however symbolic. A veteran radical named John Rogers told a public meeting at Bolton that he believed the abandonment of the divorce bill would prove to be politically counterproductive. It would only divert attention away from

85 Jeremy Caple, The Bristol Riots of 1831 and Social Reform in Britain (Lew iston, New York 1990), 96-102, 120-21; Gwyn A. Williams, The Merthyr Rising (London 1978), passim.

86 Such was one of the toasts given at the Bolton public meeting to celebrate the release of the cotton spinners from Lancaster Castle in February 1821. See Manchester Observer, 3 March 1821.

87 Belchem, 'Orator' Hunt, 147. 
the "abominable deeds" of Peterloo and facilitate a coalition of Whigs and Tories. Yet he continued :

I rejoice that the Queen has overcome them [the Tories]; I rejoice that she has all along so nobly dared them to give her a fair chance. I rejoice that Boroughmongering is conquered. I rejoice that Magistrates ... are bound to see the Reformers Flaggs thus exhibited, thus thrown into their own teeth. On these grounds I do sincerely rejoice. But not one yard further ... Let me see a standing army abolished, A National debt paid ... Let me see all useless sinecures and Pensions struck off. Let me see this Nation freely represented. Let me see it ruled by wise disinterested rulers. Then I will shake hands with the Ruling Power ... But till all this is accomplished, I will persevere in the Good Old Path of Jacobinism. ${ }^{88}$

We may regard this speech as a form of radical populism, focussing as it does upon the evils of Old Corruption. Yet it was a populism charged with class rhetoric. Certainly the language of 1820 was capable of generating "extra-proletarian" meanings, to use a choice Joycean phrase, but in the cotton towns of Lancashire, in the vortex of the industrial revolution, it resonated with the anger, despair and determination of class struggle.

This essay was read to the York History research seminar, the Early Modern British seminar in Toronto, and at the Conference of British Studies meeting at Montreal in October 1993. I thank participants for their comments, some of which have been incorporated into the final version. I should also like to thank Brett Cohen for his research assistance. 